\title{
Early Screening of Fusarium Wilt and Molecular Analysis of Banana Variants
}

\author{
H. Kishor ${ }^{1 *}$, G. Prabhuling ${ }^{2}$, Y.C. Abhijith ${ }^{3}$, N. Manjunatha ${ }^{4}$ and Y.P. Prasad ${ }^{5}$
}

${ }^{1}$ Aeroponics Centre, PRS Horticulture Farm, Chikkaballapura, Karnataka-562101, India

${ }^{2}$ Directorate of Research, University of Horticultural Sciences, Bagalkot, Karnataka, India

${ }^{3}$ Department of Fruit Science, College of Horticulture, GKVK campus, Bengaluru, India

${ }^{4}$ Department of Fruit Science, College of Horticulture, Kolar, India

${ }^{5}$ Department of Plant Pathology, University of Agricultural and Horticultural Sciences,

Shimoga, India

*Corresponding author

\section{A B S T R A C T}

Banana and plantains is the most important tropical fruit crop in the world, which serves as a major food and source of income in many countries. Bananas are severely infected by

Keywords

Mutation, FOC,

Screening,

Molecular analysis

Article Info

Accepted:

20 February 2018

Available Online:

10 March 2018 several pathogens one such Fusarium oxysoporum f. sp. Cubense which causes significant crop losses in the fields. In this study fusarium wilt screening was carried out on chemically induced mutants and molecular analysis was done to assess the acquired resistance to Fusarium oxysoporum f. sp. cubense. From the early screening we observed that Ethyl Methane Sulphonate derived mutants are more sensitive which ranged from 9.511.4\%. Whereas, several mutants obtained from Sodium Azide were resistant and was comparable with resistant cv. Poovan. Similar correlation analysis with molecular markers also revealed comparable results with the early screening. RAPD primers (OPN-06 and OPR-07) showed resistance specific bands and were used for the testing variation among mutants, after confirming its reproducibility. Putative resistant and susceptible mutants along with Poovan banana when amplified with OPN 06 showed the presence of a major band at $1500 \mathrm{bp}$ and $200 \mathrm{bp}$ which evidenced the occurrence of random mutations in genome.

\section{Introduction}

Bananas and plantains are large monocotyledonous herbs originated from southern parts of Asia (Simmonds, 1962). The evolution of cultivated bananas are the result of two diploid, seeded species of Musa, M. acuminate Colla and $M$. balbisiana Colla (Kress, 1990) contributed lot for the evolution of present day cultivars. India is also one of the region for banana diversity development in terms of varieties, landraces are among the most important ecotypes grown since time immemorial for its unique features of quality and its acclimatization to local ecological conditions. One such ecotype is Nanjanagudu Rasabale once a leading cultivar of Mysore province is now under the threat of extinction 
due its severe susceptibility to Fusarium oxysporium f. sp. cubense (Pooja et al., 2013; Khan, 2015).

When susceptible varieties are cultivated in disease infected soils, management of Fusarium wilt becomes very difficult due toits long term surveillance of fungal spores in the soil. Control of this FOC under such conditions is restricted to the use of diseasefree planting material and clean soils (Ploetz, 2006). Resistant genotypes exist for some applications, but resistance is still needed in other situations. Attempts at developing clones resistant to Fusarium oxysporum f. sp. Cubense using traditional breeding methods has been relatively weak or even restrained due to narrow genetic variability resulting from the low female fertility (Silva et al., 2001; Pua, 2007; Bidabadi et al., 2012).

Mutation breeding and biotechnological techniques may provide more possibilities for banana improvement. Mutation breeding in vitro is a powerful tool for the induction and selection of desirable mutants which can be utilized in banana improvement either for higher yields, good quality and resistance to biotic and abiotic factors (Purseglove, 1998). The mutants so produced facilitate the isolation, identification and cloning of genes used in designing crops with improved yield and quality traits (Ahloowalia and Maluszynski, 2001). Molecular markers have a number of perceived advantages over the morphological markers for the assessment of genetic diversity (Shao et al., 2010). Initially, the DNA based markers like Restriction Fragment Length Polymorphism (RFLP), Random Amplified Polymorphic DNA (RAPD), and Amplified Fragment Length Polymorphic DNA (AFLP) were used which provide excellent tools to study the genetic diversity. Later, ISSR and SRAP markers have been shown to be effective for finger printing, genetic diversity analysis and germplasm evaluation since they can identify many informative loci (Budak et al., 2004; Ruiz and Garcia-Martinez, 2006 and Liu et al., 2008).

In the light of above information, an investigation was carried out to screen the mutants against fusarium wilt and molecular analysis of these putative mutants for possible acquisition of resistance genes.

\section{Materials and Methods}

The experiments were conducted at Centre for Horticulture Biotechnology, UHS, Bagalkot, with banana cultivar Nanjanagudu Rasabale. Chemical mutations were induced by Ethyl Methane Sulphonate (EMS-0.30 \%, $0.60 \%$, $0.90 \%$ and $1.20 \%)$ and Sodium Azide $\left(\mathrm{NaN}_{3}-\right.$ $0.01 \%, 0.02 \%$ and $0.03 \%)$. The putative mutants obtained aftermutagenesis was screened against Fusarium oxysporum f. sp. cubense, Race 1.

\section{Isolation and maintenance of Fusarium pathogen}

The plants showing typical symptom viz., older leaves yellowing followed by drooping all along the stem, basal leaf sheath breakage (stem splitting) the vascular discoloration of inner core of the pseudostem and rhizome. These discolorations appeared as dark brownish red at centre with a dark brown margin surrounding the core. These infected vascular bits were surface sterilized with 0.10 per cent mercuric chloride solution for 30 seconds. The bits were washed thoroughly in sterile distilled water for three successive changes and were transferred aseptically to petriplates containing PDA medium.

The pathogenic fungus grown on PDA slants was allowed to grow at $25 \pm 1^{0} \mathrm{C}$ for 10 days and such slants were preserved in a refrigerator at $5^{\circ} \mathrm{C}$ and renewed once in 30 days. 
Measurement of cells concentration of fungal conidia

The haemocytometer was used for counting the fungal spores in liquid suspension. It is a special microscope slide with a counting chamber $0.10 \mathrm{~mm}$ deep so that volume of liquid over a one sq. $\mathrm{mm}$ is 0.10 cubic $\mathrm{mm}$.

Methodology of Fusarium oxysporum f. sp. cubense Race 1 inoculation

The putative mutants obtained from the experiment one were screened against Fusarium oxysporum f. sp. cubense, Race 1 using the procedure given by the Musoke, et al., (1999). Screening was carried out using Fusarium oxysporium f. sp. cubense Race 1 spore population adjusted to $3 \times 10^{4}$ spores $\mathrm{ml} / \mathrm{l}$ using the immersion method. Each plantlets were dipped in the spore suspension and placed on growing medium. Control plantlets were dipped in distilled water.

DNA isolation, PCR amplification and sequencing

About 2 gram leaf samples of DNA extraction were collected from putative mutants of Banana cv. Nanjanagudu Rasabale for extraction of DNA. Leaf samples were also collected from Poovan variety for comparison with the putative mutants against FOC resistance. DNA was extracted from banana variants using young cigar leaf. Standard protocol for the isolation and extraction of DNA by CTAB method was used.

Agarose solution of 0.80 per cent was prepared in 1X TAE buffer for $30 \mathrm{ml}[1.5 \%$ agarose solution for RAPD]. It was heated to dissolve completely, cooled to $40^{\circ} \mathrm{C}$, and then ethidium bromide solution $(0.5 \mathrm{~g} / \mathrm{ml})$ was added. It was then poured into the cast and the comb inserted. Nano drop spectrophotometer was used for the quantification of DNA. The blank was made with TE buffer, $2 \square 1$ of DNA sample was taken for the quantification.

The PCR reaction was carried out using Randomly Amplified Polymorphic DNARAPD markers in Master Cycler gradient 533 (Eppendorf, India). The amplified products (after PCR) were stored at $4^{0} \mathrm{C}$ till GEL electrophoresis in a $25 \square 1$ reaction volume containing $10 \mathrm{X}$ incomplete buffer, $25 \mathrm{mM} \mathrm{MgCl}_{2}, 1$ mMdNTP's, $0.30 \mu \mathrm{M}$ primers, $0.50 \mathrm{U}$ of Taq DNA polymerase (Genei, Bangalore) and $20 \mathrm{ng}$ template DNA in Eppendorf master cycler.

\section{Statistical analysis}

Analysis of variance for effect of chemical mutagens were analysed in a Completely Randomized Design (CRD). The levels of significance used for F-test was at 1 per cent probability. Critical difference values were given in the table was at 1 per cent level of significance, where the F-test was significant and used to compute the means.

\section{Results and Discussion}

Hardened plants obtained after mutagenesis was subjected to early screening for any acquired resistance to Fusarium oxysporum $\mathrm{f}$. sp. cubense Race 1. A total of 105 plants were screened and revealed varied results which can be differentiated by various external symptoms and molecular analysis. Some of results are expressed as follows.

Per cent plants with external symptoms of FOC

The reaction study of putative mutants screened against Fusarium oxysporum f. sp. cubense inoculation exhibited several noted symptoms like older leaf yellowing, plantlet wilting and pseudo stem splitting. The combinational effects of external symptoms 
were recorded in several treatments. The data pertaining to disease symptoms of the mutants are presented in the Table 1 .

Among the mutagenic treatments, maximum yellowing $(66.6 \%)$ and wilting $(33.33 \%)$ was recorded in untreated control. The maximum pseudo stem splitting (20\%) was recorded in EMS $0.30 \%$ followed by EMS $0.90 \%$ and $\mathrm{NaN}_{3} 0.01 \%$ (each $13.33 \%$ plants). The minimum stem splitting (6.66 \%) symptoms was observed in untreated control.

\section{Number of plants devoid of external symptoms of $F O C$}

The effect of Fusarium oxysporum f. sp. cubense Race 1 culture on in vitro derived mutants was found to be effective in inducing resistant plants among the treatments. The highest number of plants (3) with no external symptoms was obtained from $\mathrm{NaN}_{3} 0.01 \%$. The treatments EMS at $0.30 \%, 0.90 \%, \mathrm{NaN}_{3}$ at $0.02 \%$ and $\mathrm{NaN}_{3}$ at $0.03 \%$ have also recorded minimum number of plants (1) with no external symptoms of $F O C$ Race 1.

External symptoms exhibited by the plants included leaf yellowing, wilting and pseudostem splitting were recorded. The effects of Fusarium oxysporum f. sp. cubense Race 1 culture on various chemical mutants showed varied symptoms. Our results are comparable with the results of Chen et al., (2013) statements, Brazil banana plantlets began to show external symptoms of fusarium wilt within 10-14 days of inoculation with FOC race 4 , but Zhongshan Dajiao plantlets were resistant to $F O C$ race 4 and did not show any symptoms. In Brazil banana plantlets, the first symptom was yellowing of lower leaves, which began along the margin and advanced toward the midribs. Subsequently, brown spots appeared on the leaves, followed by browning of petioles and buckling, and these symptoms developed from older to younger leaves. The injured roots of the in vitro derived plantlets dipped in FOC spore suspension showed symptoms of fusarium wilt within fifth day of incubation. The leaf veins showed chlorosis gradually entire lamina turned yellow and resulted in the wilting of the leaves as reported by Krishna et al., (2013). The partially resistant plantlets exhibiting the symptoms were recorded. Among the mutants maximum external symptoms are exhibited by control plantlets which showed maximum susceptibility to FOC. This is because of a differential response of the genomic composition of the cultivar to Fusarium oxysporum f. sp. cubense Race 1 culture.

\section{Analysis by using RAPD markers}

It was difficult to distinguish these mutants using traditional morphological or phenotypic differences. Random amplified polymorphic DNA markers were used to detect the variation among the resistant and susceptible mutants. OPN, OPJ, OPS, OPT, OPA and OPR series primers were used to determine genetic variation between the various phenotypic mutants, resistant and susceptible mutants along with mother plant.

For molecular analysis 10 Operon primers were used. Among these 09 primers showed amplification and 03 primers amplified unambiguous, readable and showed polymorphic bands. A total of 631 amplification products were produced from the selected 09 primers and the number of bands varied from 1-11 with an average of 7.7 bands per primer. The bands which are more than $100 \mathrm{~kb}$ are selected for analysis. The details are presented in Table 2. Each and every individual could be identified using gel profiles. A polymorphism was found among the various phenotypic mutants and mother plant, resistant and susceptible plant indicating there was a high molecular variability among the mutants. 
Plate.1 Response of putative banana mutants to Fusarium oxysporum f. sp. cubense Race 1

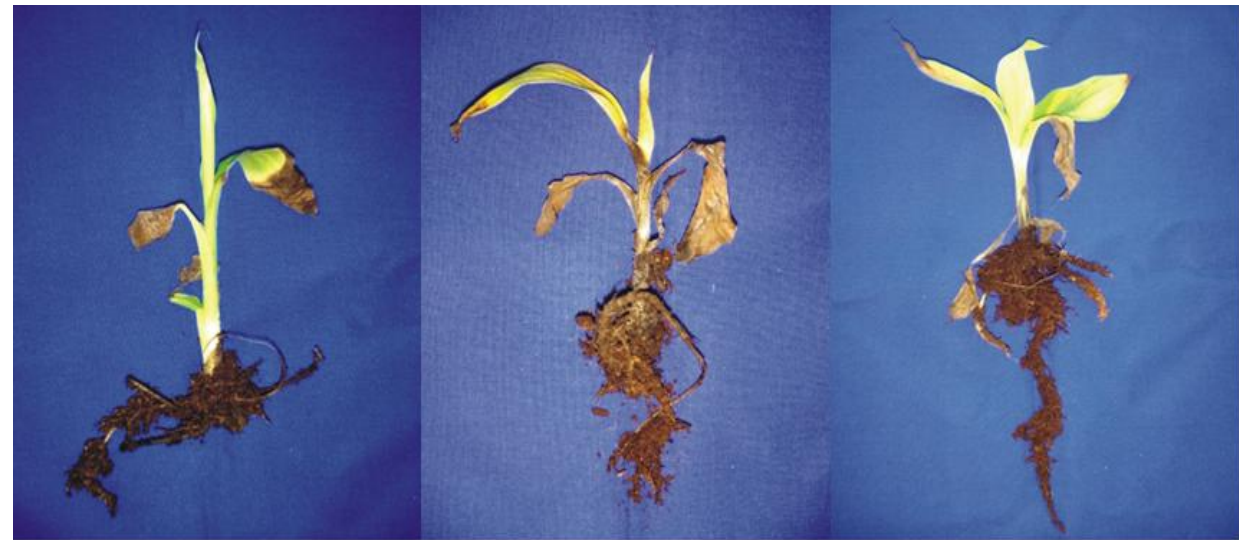

a) Initial symptoms (b) Yellowing

(c) Stem splitting

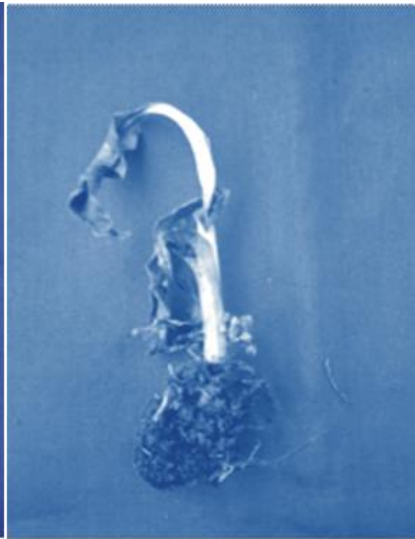

(d) Wilting

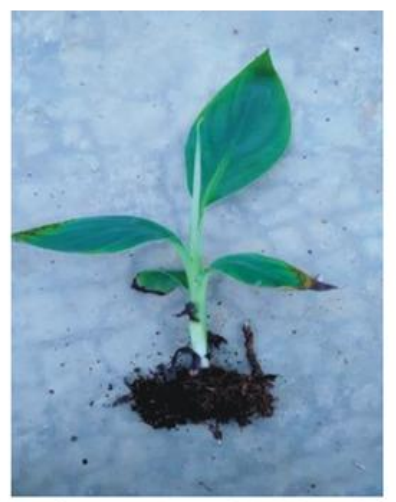

(e) Resistant plant $\left(\mathrm{NaN}_{3}\right.$ at $\left.0.01 \%\right)$

Plate.2 RAPD profile of Poovan, FOC resistant and susceptible mutants obtained with OPN 06

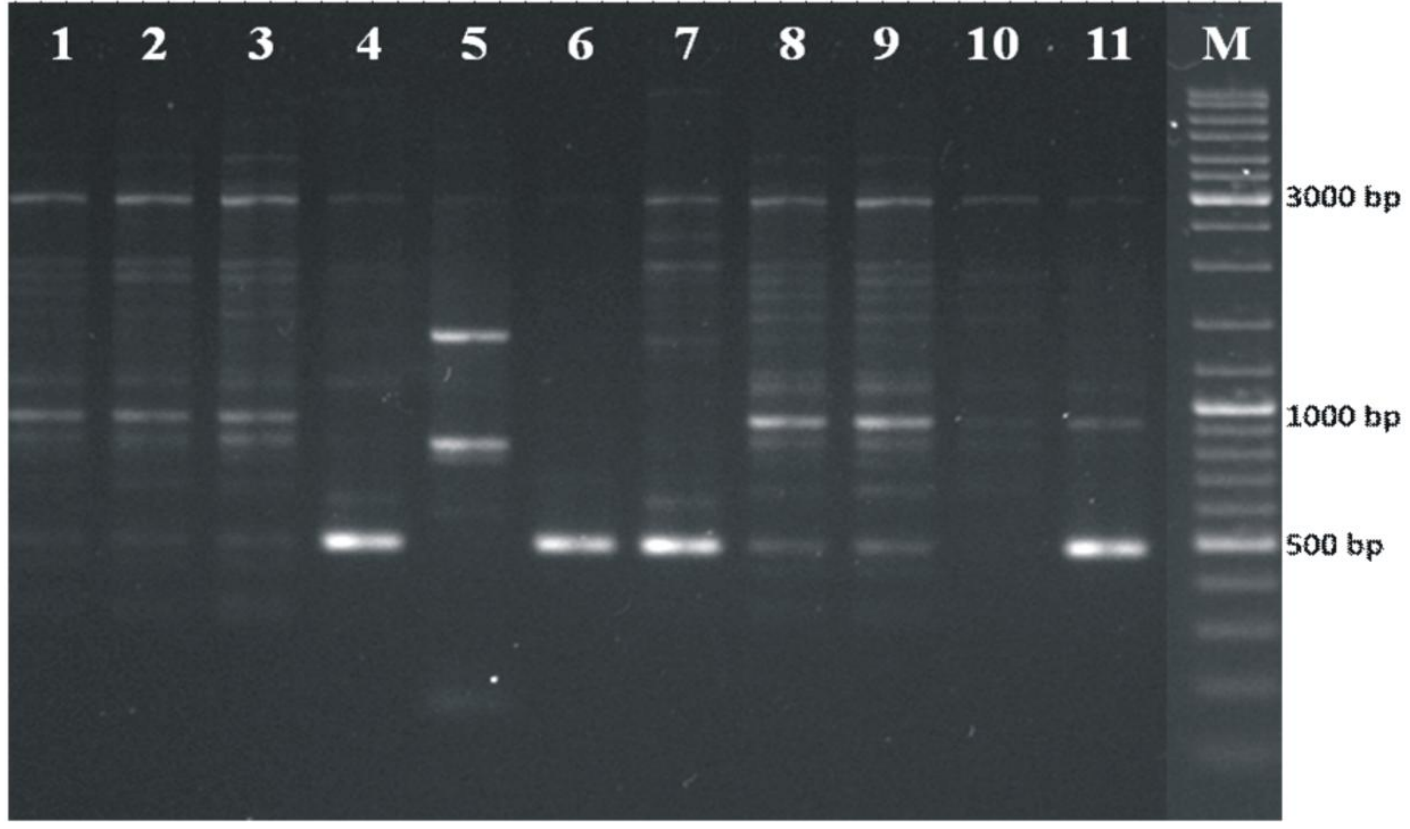


Plate.3 RAPD profile of Poovan, FOC resistant and susceptible mutants obtained with OPR 07

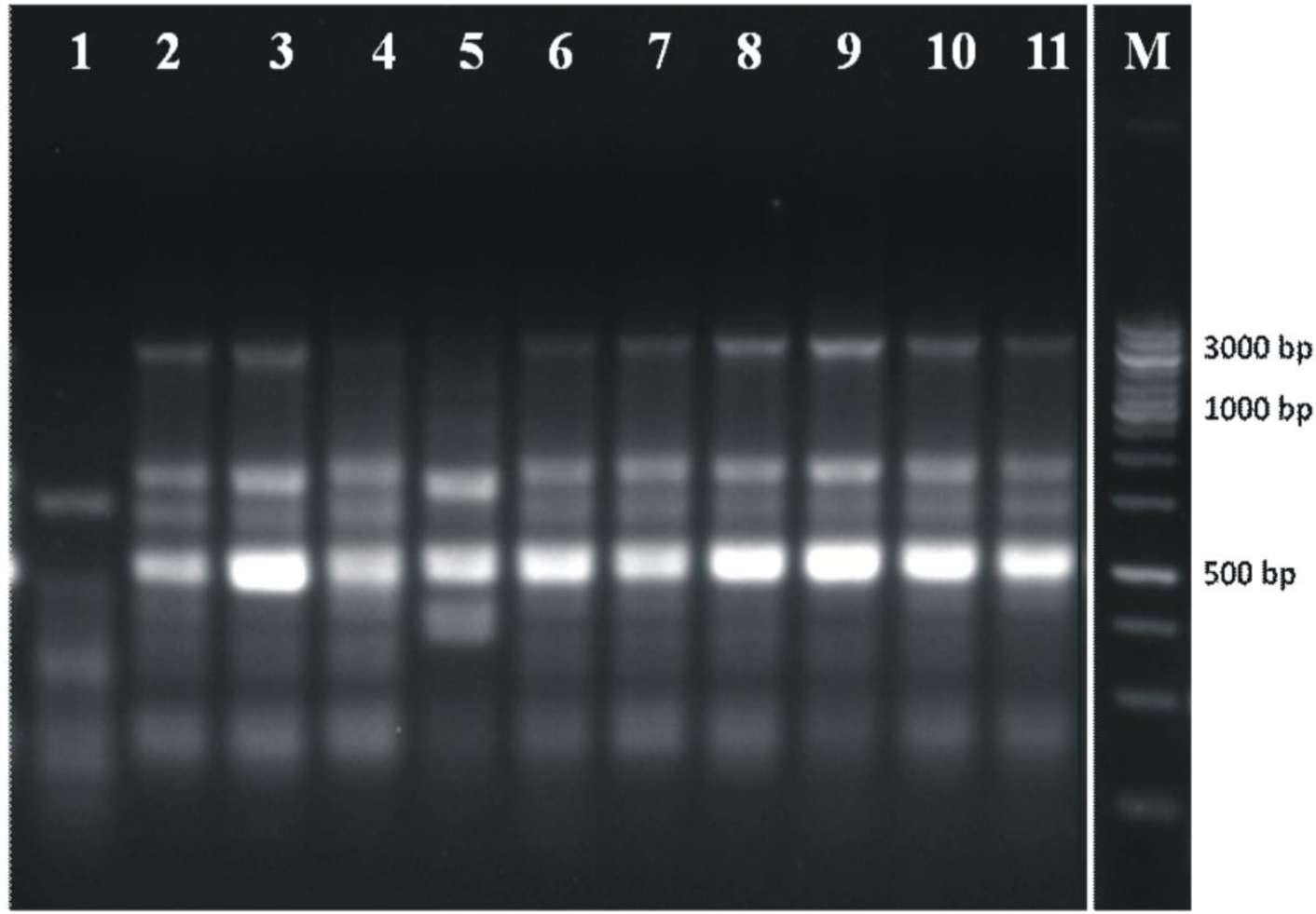

Legends; 1-Poovan, 2,3,4- Resistant mutants of $\mathrm{NaN}_{3}$ at $0.01 \%$, 5- Resistant mutants of $\mathrm{NaN}_{3}$ at $0.02 \%$, 6- Resistant mutant of $\mathrm{NaN}_{3}$ at $0.03 \%$, 7- Resistant mutant of EMS at $0.90 \%, 8$ - Susceptible mutant of $\mathrm{NaN}_{3}$ at $0.01 \%$, 9Susceptible mutant of $\mathrm{NaN}_{3}$ at $0.02 \%, 10$-Susceptible mutant of $\mathrm{NaN}_{3}$ at $0.03 \%, 11$-Susceptible mutant of EMS at $0.90 \%$

Table.1 The response of putative mutants of banana cv. Nanjanagudu Rasabale on artificial inoculation of Fusarium oxysporum $\mathrm{f}$. sp. cubense Race 1

\begin{tabular}{|c|c|c|c|c|}
\hline \multirow[t]{2}{*}{ Treatments } & \multicolumn{3}{|c|}{$\begin{array}{l}\text { Per cent plants with external } \\
\text { symptoms of } F O C\end{array}$} & \multirow{2}{*}{$\begin{array}{c}\text { Per cent plants with } \\
\text { no external } \\
\text { symptoms }\end{array}$} \\
\hline & $\begin{array}{l}\text { Older leaf } \\
\text { yellowing }\end{array}$ & $\begin{array}{l}\text { Plantlet } \\
\text { wilting }\end{array}$ & $\begin{array}{l}\text { Pseudo } \\
\text { stem } \\
\text { splitting }\end{array}$ & \\
\hline $\mathrm{T}_{1}$-EMS at $0.30 \%$ & 40 & 33.33 & 20 & 1 \\
\hline $\mathrm{T}_{2}$-EMS at $0.60 \%$ & 33.33 & 26.66 & 0 & 0 \\
\hline $\mathrm{T}_{3}$-EMS at $0.90 \%$ & 46.66 & 26.66 & 13.3 & 1 \\
\hline $\mathrm{T}_{4}$-EMS at $1.20 \%$ & 0 & 0 & 0 & 0 \\
\hline $\mathrm{T}_{5}-\mathrm{NaN}_{3}$ at $0.01 \%$ & 40 & 20 & 13.33 & 3 \\
\hline $\mathrm{T}_{6}-\mathrm{NaN}_{3}$ at $0.02 \%$ & 60 & 26.66 & 0 & 1 \\
\hline $\mathrm{T}_{7}-\mathrm{NaN}_{3}$ at $0.03 \%$ & 53.33 & 20 & 0 & 1 \\
\hline $\begin{array}{c}\mathrm{T}_{8} \text {-Untreated } \\
\text { control. }\end{array}$ & 66.66 & 33.33 & 6.66 & 0 \\
\hline Total & 49.52 & 26.66 & 7.61 & 7 \\
\hline
\end{tabular}


Table.2 Analysis of genetic variation using random operon primers

\begin{tabular}{|c|c|c|c|c|}
\hline Primers & $\begin{array}{c}\text { Nucleotide } \\
\left.\text { sequence (3' to } \mathbf{5}^{\prime}\right)\end{array}$ & Total bands & $\begin{array}{c}\text { Polymorphic } \\
\text { bands }\end{array}$ & $\begin{array}{c}\text { Monomorphic } \\
\text { bands }\end{array}$ \\
\hline OPJ 10 & AAGCCCGAGG & 100 & 78 & 22 \\
\hline OPJ 16 & CTGCTTAGGG & 67 & 38 & 29 \\
\hline OPN 06 & GAGACGCACA & 121 & 96 & 25 \\
\hline OPN 04 & AAGCGACCTG & 55 & 37 & 18 \\
\hline OPN 16 & AAGCGACCTG & 88 & 60 & 28 \\
\hline OPR 07 & ACTGGCCTGA & 88 & 70 & 18 \\
\hline OPR 08 & CCCGTTGCCT & 101 & 90 & 11 \\
\hline & Total & 620 & 469 & 151 \\
\hline
\end{tabular}

The seven primers used provided a large number of polymorphism among the resistant, susceptible mutants, morphological mutants and mother plant. Only few of the bands observed were specifically shared either by resistant, susceptible mutants, phenotypic mutants and mother plant. Putative resistant and susceptible mutants along with Poovan banana when amplified with OPN 06 showed the presence of a major band at $1500 \mathrm{bp}$ and $200 \mathrm{bp}$ in lane 5 and absence of the band in all other lanes shows the polymorphism of the mutant lines. With OPR 07 absence of a major band at $600 \mathrm{bp}$ and presence of major band at $400 \mathrm{bp}$ in lane 5 was clearly indicating the changes under molecular level. These bands may be associated with the resistant character of putative mutants (Plate 2\&3).

\section{Molecular analysis}

Observing to the banding pattern of RAPD primer OPN-06, it was clear that $1500 \mathrm{bp}$ and $200 \mathrm{bp}$ band size was found to be resistance specific since it was absent in mother plant and susceptible individuals and other resistant mutants. Observing to the banding pattern of another RAPD primer OPR-07, it was clear that absence of a major band at $600 \mathrm{bp}$ and presence of band at $400 \mathrm{bp}$ in lane 5 is clearly indicating the changes in molecular level was found be resistance specific. Javed et al.,
(2004) reported that $1.0 \mathrm{k} \mathrm{bp}$ band derived from the primer-21 was observed to be present only in the resistant and absent in the susceptible seed progenies resistant of Musa acuminate to Fusaruim oxysporum using RAPD markers. Damasco et al., (1996) successfully demonstrated the use of RAPD markers and detected a marker linked with dwarfness in Cavendish bananas.

External symptoms exhibited by the plants included leaf yellowing, wilting and pseudostem splitting were recorded. The effect of Fusarium oxysporum f. sp. cubense culture on various chemical mutants showed varied symptoms. Our results are comparable with the results of Chen et al., (2013) statements, Brazil banana plantlets began to show external symptoms of fusarium wilt within 10-14 days of inoculation with FOC race 4 , but Zhongshan Dajiao plantlets were resistant to $F O C$ race 4 and did not show any symptoms. In Brazil banana plantlets, the first symptom was yellowing of lower leaves, which began along the margin and advanced toward the midribs. Subsequently, brown spots appeared on the leaves, followed by browning of petioles and buckling, and these symptoms developed from older to younger leaves. The injured roots of the in vitro derived plantlets dipped in FOC spore suspension showed symptoms of fusarium wilt within fifth day of incubation. The leaf 
veins showed chlorosis gradually entire lamina turned yellow and resulted in the wilting of the leaves as reported by Krishna et al., (2013). The partially resistant plantlets exhibiting the symptoms were recorded. Among the mutants maximum external symptoms are exhibited by control plantlets which showed maximum susceptibility to FOC. This is because of a differential response of the genomic composition of the cultivar to Fusarium oxysporum f. sp. cubense Race 1 culture.

\section{References}

Ahloowalia, B. S, and Maluszynski, M., 2001, Induced mutations: A new paradigm in plant breeding. Euphytica., 118: 167173.

Bidabadi, S.S., Sariah, M., Zakaria, W., Sreeramanan, S. and Maziah, M., 2012, Induced mutations for enhancing variability of banana (Musa spp.) shoot tip cultures using ethyl methanesulphonate (EMS). Aust. J. Crop Sci., 6 (3): 391-401

Budak, H., Shearman, R.C., Parmaksiz, I. and Dweikat, I, 2004, Comparative analysis of seeded and vegetative biotype buffalo grasses based on phylogenetic relationship using ISSRs, SSRs, RAPDs, and SRAPs. Theor. Appl. Genet., 109: 280-288.

Capdeville, G., Souza, M.T., Szinay, D., Wijnker, E. and De-Jong, H., 2009, The potential of high-resolution BAC-FISH in banana breeding. Euphytica., 166: 431-443.

Chen, Y.F., Chen, W., Huang, X., Hu, X., Zhao. J.T., Gong, Q., Li, J. and Huang, L., 2013, Fusarium wilt-resistant lines of Brazil banana (Musa spp., AAA) obtained by EMS-induced mutation in a micro-cross-section cultural system. Plant Pathol, 62 (1): 112-119.
Chopra, V.L., 2005, Mutagenesis: investigating the process and processing the outcome for crop improvement. Curr. Sci., 89: 353-359.

Damasco, O.P., Graham, G.C., Henry, R.J., Adkins, S.W., Smith, M.K. and Godwin, I.D., 1996, Random amplified polymorphic DNA (RAPD) detection of dwarf off-types in micropropagated Cavendish (Musa spp., AAA) bananas. Plant mutat. Rep. 16: 118-123.

Javed, M. A., Chai, M. and Othman, R. Y., 2004, Study of resistance of Musa acuminata to Fusarium oxysporum using RAPD markers. Biologia plantarum, 48 (4): 93-99.

Khan, A.L., 2015, Only 30 acres for exotic Nanjangudu Rasabale. The Hindu., daily newspaper dated January 30.

Kress, W. J. 1990. The phylogeny and classification of the Zingiberales. Ann. Mo. Bot. Gard. 77:698-721.

Krishna, V.V., Kumar, K.G., Pradeepa, K., Kumar, S.R.S. and Kumar, R.S., 2013, Biochemical markers assisted screening of Fusarium wilt resistant Musa paradisiaca (L.) cv. Puttabale micropropagated clones. Indian J. Exp. Biol., 51:531-542.

Liu, P.L., Zhao, L.P., Gong, Y.Q., Wang, M.X., Chen, L.M., Yang, J.L., Wang, Y., Yu, F.M. and Wang, L.Z., 2008, DNA fingerprinting and genetic diversity analysis of late-bolting radish cultivars with RAPD, ISSR and SRAP markers. Sci. Hort., 116: 240-247.

Musoke, C., Rubaihayo and Magambo, M., 1999, Gamma Rays and Ethylmethane Sulphonate In vitro Induced Fusarium Wilt Resistant Mutants in Bananas. Afr. Crop Sci. J., 7 (4): 313-320.

Ploetz, R. C., 2006, Fusarium Wilt of Banana Is Caused by Several Pathogens Referred to as Fusarium oxysporum f. sp. cubense. Symposium- Fusarium- 
Induced Diseases of Tropical Perennial Crops, 96 (6): 653-656.

Pooja, B., Ajit, A.W. and Umesha, K., 2013, Preliminary assessment of intra-clonal variations in Indian banana varieties for sucker production. Ind. J. Natural products and resources., 4 (4) : 387 391.

Pua, E.C., 2007, Banana. In: Pua EC, Davey MR (eds), Biotechnology in Agriculture and Forestry. Springer-Verlag., 60: 334.

Purseglove, J. W., 1998, Tropical crops. Monocotyledons. Longman Scientific and Technical. Longman Group UK. Ltd. Pp. 607.

Ruiz, J.J. and Garcia-Martinez, S., 2006, Genetic variability and relationship of closely related Spanish traditional cultivars of tomato as detected by SRAP and SSR markers. J. American Soc. Hort. Sci., 130: 88-94.

Shao, Q.S., Guo, Q.S, Deng, Y.M. and Guo, H.P., 2010, A comparative analysis of genetic diversity in medicinal Chrysanthemum morifolium based on morphology, ISSR and SRAP markers. Biochem. Sys. Ecol., 38:1160-1169.

Silva, S.O., Junior, M. S., Alves, E. J., Silveira, J. S. and Lima, M. B., 2001, Banana breeding program at EMBRAPA. Crop Breed Appl. Biotechnol., 1 (4): 399-436.

Simmonds, N. W. 1962. The Evolution of the Bananas. Longmans, London, UK.

\section{How to cite this article:}

Kishor, H., G. Prabhuling, Y.C. Abhijith, N. Manjunatha and Prasad, Y.P. 2018. Early Screening of Fusarium Wilt and Molecular Analysis of Banana Variants. Int.J.Curr.Microbiol.App.Sci. 7(03): 2313-2321. doi: https://doi.org/10.20546/ijcmas.2018.703.271 